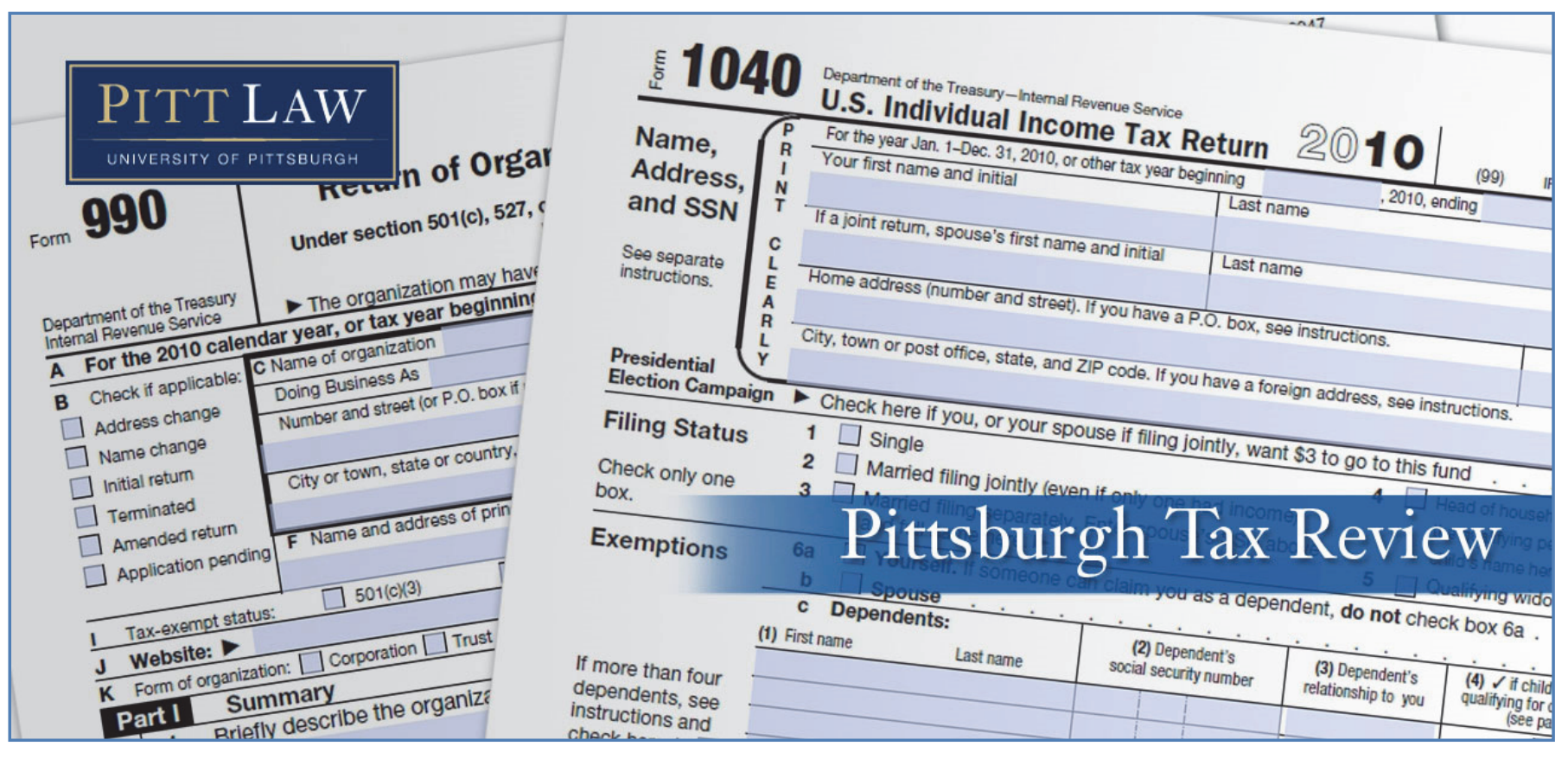

Volume 16 (2018) | ISSN 1932-1821 (print) 1932-1996 (online)

DOI 10.5195/taxreview.2018.82 | http://taxreview.law.pitt.edu

\title{
PROTECTING THE (TAX) BASE: ANTI-BASE EROSION PROVISIONS IN THE TAX CUTS AND JOBS ACT
}

\section{Michael Bauer}

\section{(c) BY-NC-ND}

This work is licensed under a Creative Commons Attribution-Noncommercial-No Derivative Works 3.0 United States License.

\section{ULLS D-Sork}

This journal is published by the University Library System of the University of Pittsburgh as part of its D-Scribe Digital Publishing Program, and is cosponsored by the University of Pittsburgh Press. 


\title{
PROTECTING THE (TAX) BASE: ANTI-BASE EROSION PROVISIONS IN THE TAX CUTS AND JOBS ACT
}

\author{
Michael Bauer*
}

They said that tax reform was going to make computing and filing taxes less complicated. ${ }^{1}$ Good for taxpayers, bad for tax practitioners (like me). I suppose the jury is still out, but the early results suggest that "they" were wrong. Part of the complexity introduced by the Tax Cuts and Jobs $\mathrm{Act}^{2}$ (TCJA) revolves around one of the initial goals of tax reform: a shift from a worldwide system of taxation to a territorial system. ${ }^{3}$ A territorial system, by definition, has a smaller tax base-if adopted by the United States, a territorial system would only tax income earned in the United States. ${ }^{4}$ Although one could certainly question whether the TCJA made any meaningful strides towards a full territorial system or if it instead created a more complex worldwide tax system, the TCJA did introduce several provisions designed to protect the domestic tax base..$^{5}$ These "anti-base erosion" provisions act as a backstop to the new participation exemption system and the reduced corporate tax rate. ${ }^{6}$ They are designed to incentivize U.S. multinational companies to relocate overseas earnings and activities to

${ }^{*}$ B.A., University of Wisconsin-Whitewater, 2003; J.D., University of Pittsburgh School of Law, 2007; LL.M, Georgetown University Law Center, 2011. Michael Bauer focuses his practice on the taxation of financial products.

${ }^{1}$ See, e.g., Adam Michel, Tax Reform 2.0: Priorities After the Tax Cuts and Jobs Act of 2017, HERITAGE FOUND. (Mar. 22, 2018), https://www.heritage.org/taxes/report/tax-reform-20-priorities-afterthe-tax-cuts-and-jobs-act-2017.

${ }^{2}$ Tax Cuts and Jobs Act, Pub. L. No. 115-97, 131 Stat. 2054 (2017).

${ }^{3}$ E.g., Molly F. Sherlock \& Donald J. Marples, Cong. ReSearch SerV., R45092, The 2017 TAX REVISION (P.L. 115-97): COMPARISON TO 2017 TAX LAW 1 (2018), https://fas.org/sgp/crs/misc/ R45092.pdf.

${ }^{4}$ See id. at 41 tbl.2.

${ }^{5}$ Tax Cuts and Jobs Act $\S \S 13301(a), 14401$ (a), 131 Stat. at 2117-21, 2226 (codified at $\S \S 59 \mathrm{~A}$, $163(\mathrm{j}))$.

${ }^{6} I d$.

Pitt Tax Review | ISSN 1932-1821 (print) 1932-1996 (online)

DOI 10.5195/taxreview.2018.82 | http://taxreview.law.pitt.edu 
the United States, and they aim to level the playing field for U.S. multinational companies as compared to their foreign competitors. Two notable provisions in the TCJA are new $\S 163(\mathrm{j})$ and the base erosion and antiabuse tax (BEAT). Together these two sections, discussed in more detail below, provide a significant line of defense against excess deductions that could otherwise erode the U.S. tax base - thus protecting the tax base.

\section{SECTION 163(J) EARNINGS STRIPPING}

\section{A. "Old” Section 163(j)}

Section 163(j) was "amended" as part of the TCJA. ${ }^{7}$ The use of quotations is intentional. Although new $\S 163(\mathrm{j})$ was nominally drafted as an "amendment" to then-existing § 163(j) (what I will refer to as "old $\S 163(\mathrm{j})$ )"), it replaced old $\S 163(\mathrm{j})$ in its entirety. ${ }^{8}$ For this reason, it is generally easier to think of amended $\S 163(\mathrm{j})$ as a new section. Nevertheless, understanding old $\S 163(\mathrm{j})$ is still useful in understanding new $\S 163(\mathrm{j})$.

Old $\S 163(\mathrm{j})$ was added to the Code in 1989 as an "earnings stripping" provision designed to prevent U.S. tax base erosion through excessive interest expense deductions for interest paid or accrued by corporations to foreign related parties, where such interest expense was fully or partially exempt from U.S. federal income tax. ${ }^{9}$

Importantly, old $\S 163(\mathrm{j})$ 's application was limited to certain thinly capitalized corporations - it applied to corporations that had a debt-to-equity ratio exceeding $1: 1.5$ at the end of the corporation's taxable year. ${ }^{10}$ If a corporation was subject to old $\S 163(\mathrm{j})$, its deduction for interest expense was limited to the extent that its net interest expense exceeded $50 \%$ of the corporation's "adjusted taxable income" for the year. ${ }^{11}$ Interest expense not

\footnotetext{
${ }^{7} I d . \S 13301(\mathrm{a}), 131$ Stat. at 2117-21 (codified at $\left.\S 163(\mathrm{j})\right)$.

${ }^{8} I d$.

${ }^{9}$ See Omnibus Budget Reconciliation Act of 1989, Pub. L. No. 101-239, § 7210(a), 103 Stat. 2106, $2339-42$ (codified at $\$ 163(\mathrm{j})$ ). The limitation also applied to interest paid or accrued to unrelated persons if the debt was guaranteed by a related person. See I.R.C. § 163(j)(3)(B), (6)(C) (2017).

${ }^{10}$ I.R.C. $\S 163(\mathrm{j})(2)(\mathrm{A})(\mathrm{ii})(2017)$.

${ }^{11} I d$. $\S 163(\mathrm{j})(2)(\mathrm{B})(\mathrm{iii})(\mathrm{I})$. If a corporation was a partner in a partnership, the corporate partner's distributive share of any interest income and/or interest expense paid or accrued by the partnership was
}

Pitt Tax Review | ISSN 1932-1821 (print) 1932-1996 (online) DOI 10.5195/taxreview.2018.82 | http://taxreview.law.pitt.edu 
allowed as a deduction ("disallowed interest expense carryforward") could be carried over indefinitely (and treated as incurred in such subsequent years). ${ }^{12}$ Moreover, to the extent that $50 \%$ of the corporation's adjusted taxable income exceeded its net interest expense, this excess (referred to as "excess limitation") could be carried forward for three years (and used to "free up" interest expense deductions in such future years). ${ }^{13}$

\section{B. "New” Section 163(j)}

New $\S 163(\mathrm{j})$, applicable for taxable years beginning after December $31,2017,{ }^{14}$ applies much more broadly than old $\S 163(\mathrm{j})$. As a threshold matter, new $\S 163(\mathrm{j})$ dispenses with the debt-to-equity ratio requirement in old $\S 163(\mathrm{j})$, and therefore applies regardless of whether the company is thinly capitalized or not. ${ }^{15}$ In addition, new $\S 163(\mathrm{j})$ applies to all taxpayers - not solely corporate taxpayers. ${ }^{16}$ There are specific (and quite complicated) rules addressing its application to partnerships that I will not address here. In any event, by broadening the base of taxpayers to whom $\S 163(\mathrm{j})$ applies, and expanding it to cover all "business" interest expense (i.e., not solely related party interest expense), new $\S 163(\mathrm{j})$ requires taxpayers-including those to which old $\S 163(\mathrm{j})$ applied-to reassess their capital structure, and their ability to deduct interest expense.

New $\S 163(j)$ introduces a new term: "business interest." " Specifically, new $\S 163(\mathrm{j})$ disallows a taxpayer's deduction of "business interest expense"

treated as interest income and/or expense paid or accrued by the corporate partner itself for purposes of old $\S 163(\mathrm{j}) . I d . \S 163(\mathrm{j})(8)(\mathrm{A})-(\mathrm{B})$.

${ }^{12} I d . \S 163(\mathrm{~d})(2),(\mathrm{j})(2)(\mathrm{B})(\mathrm{i})(\mathrm{II})-(\mathrm{ii})$.

${ }^{13} I d . \S 163(\mathrm{j})(2)(\mathrm{B})(\mathrm{i})(\mathrm{II})-(\mathrm{iii})$. A corporation and any members of the same affiliated group (as defined by $\S 1504(\mathrm{a})$ ) were treated as a single taxpayer for purposes of old $\S 163(\mathrm{j})$, regardless of whether the taxpayer and its affiliated group members filed a consolidated return (the "super-affiliation rules").

${ }^{14}$ See Tax Cuts and Jobs Act, Pub. L. No. 115-97, § 13301(a), (e), 131 Stat. 2054, 2117-21, 2123 (2017) (codified at $§ 163(j)$ ).

${ }^{15}$ See I.R.C. $\S 163(\mathrm{j})(2)(\mathrm{A})$.

${ }^{16} I d . \S 163(\mathrm{j})(3)-(4)$.

${ }^{17} I d . \S 163(\mathrm{j})(1)$. Although "floor plan financing interest" technically falls within the definition of business interest expense, such interest expense is specifically included in determining the business interest expense limitation and thus, not subject to limitation under $\S 163(\mathrm{j})$. See id. §163(j)(1)(C).

Pitt Tax Review | ISSN 1932-1821 (print) 1932-1996 (online) DOI 10.5195/taxreview.2018.82 | http://taxreview.law.pitt.edu 


\section{4 | Pittsburgh Tax Review | Vol. 162018}

to the extent that such amount exceeds the sum of "business interest income" for such taxable year, $30 \%$ of adjusted taxable income, and floor plan financing interest. ${ }^{18}$ Similar to old $\S 163(\mathrm{j})$, business interest expense not allowed as a deduction for any taxable year ("disallowed interest expense") is treated as business interest expense paid or accrued in the succeeding taxable year; however, taxpayers are no longer allowed to carryforward any excess limitation. ${ }^{19}$

"Business interest" is defined as any interest paid or accrued "on indebtedness properly allocable to a trade or business." "20 "Business interest" does not include "investment interest," generally defined as any deductible interest, which is paid or accrued on debt related to investment property. ${ }^{21}$ "Business interest income" is defined as the amount of interest "properly allocable to a trade or business" which is includible in a taxpayer's gross income for the taxable year (not including investment income). ${ }^{22}$ Interestingly, the definitions of business interest income and business interest expense are not symmetrical. ${ }^{23}$ The expense side is limited to interest on indebtedness, and therefore would not seem to apply to amounts deductible as interest for tax purposes that do not relate to indebtedness (e.g., imputed interest under $\S 483) .{ }^{24}$ The definition of interest income does not contain the qualifier "on indebtedness," and thus would seem to include any amounts treated as interest for tax purposes, irrespective of whether there is

${ }^{18} I d . \S 163(\mathrm{j})(1)$.

${ }^{19} I d . \S 163(\mathrm{j})(2) ; c f . i d . \S 163(\mathrm{j})(3)(\mathrm{B}),(6)(\mathrm{C})(2017)$.

${ }^{20} I d . \S 163(\mathrm{j})(5)(2018)$.

${ }^{21} I d . \S 163(\mathrm{~d})(3)(\mathrm{A})-(\mathrm{B}),(\mathrm{j})(5),(7)(\mathrm{A})$.

${ }^{22}$ Id. § 163(j)(6); see H.R. REP. No. 115-466, at 386 n.688 (2017) (Conf. Rep.) (“[A] corporation has neither investment interest nor investment income within the meaning of section 163(d). Thus, interest income and interest expense of a corporation is properly allocable to a trade or business, unless such trade or business is otherwise explicitly excluded from the application of the provision.").

${ }^{23}$ I.R.C. $\S 163(\mathrm{j})(1) ; c f . i d . \S 163(\mathrm{j})(5)$.

${ }^{24}$ See id. § 163(j)(5).

Pitt Tax Review | ISSN 1932-1821 (print) 1932-1996 (online) DOI 10.5195/taxreview.2018.82 | http://taxreview.law.pitt.edu 
indebtedness. ${ }^{25}$ The legislative history does not reflect an intent to provide for this asymmetrical treatment. ${ }^{26}$

As discussed, a taxpayer's ability to deduct interest is largely a function of its "adjusted taxable income." 27 Under new $\S 163(j)(8)(A)$, "adjusted taxable income" means taxable income computed without regard to: (1) any non-trade or business income, gain, deduction, or loss; (2) "any business interest [expense] or business interest income"; (3) "the amount of any net operating loss deduction"; (4) qualified business income deductions (under $\S 199 \mathrm{~A}$ ); and (5) for taxable years beginning before January 1, 2022, "any deduction allowable for depreciation, amortization, or depletion." Section $163(\mathrm{j})$ is thus the opposite of fine wine - it gets worse with time. ${ }^{28}$ Beginning in 2022, taxpayers' net business interest expense deductions will be limited to $30 \%$ of earnings before interest and taxes (EBIT) (e.g., there will be no addback of depreciation, amortization, or depletion), plus any floor plan financing interest. ${ }^{29}$

As noted above, new $\S 163(\mathrm{j})$ broadened the application of old $\S 163(\mathrm{j})$ to apply to all taxpayers, including partnerships. ${ }^{30}$ It also contains a number of exceptions (some of which are elective). ${ }^{31}$ Specifically, $\S 163(\mathrm{j})(7)$ excludes from the definition of "trade or business": (1) "performing services as an employee"; (2) "any electing real property trade or business"; (3) "any electing farming business"; and (4) certain utilities providers. ${ }^{32}$ It pays to have friends in high places.

${ }^{25} I d . \S 163(\mathrm{j})(1)$.

${ }^{26}$ See H.R. REP. No. 115-466, at 386-87.

${ }^{27}$ I.R.C. $\S 163(\mathrm{j})(1)(\mathrm{B})$.

${ }^{28}$ David Lee Murphy (author of the country classic Dust on the Bottle, released in 1994) no doubt is shaking his head in disapproval - it's supposed to get sweeter with time!

${ }^{29}$ I.R.C. $\S 163(\mathrm{j})(8)(\mathrm{A})(\mathrm{v})$. Section 163(j) also grants the Secretary of the Treasury the authority to make additional adjustments in order to determine adjusted taxable income for purposes of $\S 163(\mathrm{j})$, which may further reduce the limitation amount and therefore reduce the amount of interest expense available for a deduction. See id. $\S 163(\mathrm{j})(8)(\mathrm{B})$.

${ }^{30} I d . \S 163(\mathrm{j})(4)$.

${ }^{31}$ See id. $\S 163(\mathrm{j})(7)$.

${ }^{32} I d$. $\S 163(\mathrm{j})(7)(\mathrm{A})$. Note that the special depreciation rules in $\S 168(\mathrm{k})$ (which permit $100 \%$ depreciation for certain property acquired between September 29, 2017 and December 31, 2022) do not

Pitt Tax Review | ISSN 1932-1821 (print) 1932-1996 (online) DOI 10.5195/taxreview.2018.82 | http://taxreview.law.pitt.edu 
Finally, pursuant to recent IRS guidance discussed below, ${ }^{33}$ new $\S 163(\mathrm{j})$ is expected to apply on a consolidated group basis. ${ }^{34}$ Accordingly, if one member of a group (e.g., the group treasury entity) has a significant amount of debt (but limited taxable income), while another group member has significant taxable income (but minimal interest expense), the income from the latter group member will be considered in determining the deductibility of the group's business interest expense. ${ }^{35}$

\section{Regulatory and Administrative Guidance}

The first guidance under new $\S 163(\mathrm{j})$ came in the form of IRS Notice 2018-28, which was released on April 16, 2018. ${ }^{36}$ Notice 2018-28 provides that the Treasury and IRS intend to issue proposed regulations that will address a number of issues, including the interaction of new $\S 163(\mathrm{j})$ with the new $\S 59$ A, which relates to the BEAT. ${ }^{37}$ Specifically, Notice 2018-28 provides that the disallowed interest expense under old $\S 163(\mathrm{j})$ that was paid or accrued to a foreign related party and carried forward to a taxable year beginning after December 31, 2017, which is otherwise deductible in such year, will be treated as a base erosion payment for purposes of $\S 59 \mathrm{~A} .^{38}$

apply to property used in a trade or business by certain regulated utilities exempted from the application of $\S 163(\mathrm{j})$. Id. $\S 168(\mathrm{k})(9)(\mathrm{A})$. Additionally, certain taxpayers with floor plan financing, under $\S 163(\mathrm{j})(9)$, are not permitted to use the special depreciation rules under $\S 168(\mathrm{k})$. Id. $\S 168(\mathrm{k})(9)(\mathrm{A})$. Although the scope of this exclusion (e.g., whether it applies to all property of the taxpayer or only property financed with floor plan financing) is unclear. See id.

${ }^{33}$ See infra Part I.C.

${ }^{34}$ See I.R.S. Notice 2018-28, § 5, 2018-16 I.R.B. 492, 494.

${ }^{35} \mathrm{Id}$. at 492. The Tax Cuts and Jobs Act also removed the old rule which treated an affiliated group as one taxpayer, as well as the super-affiliation rules. See Tax Cuts and Jobs Act, Pub. L. No. 115-97, $\S 13301(a), 131$ Stat. 2054, 2117-21 (2017) (codified at $§ 163(j)$ ).

${ }^{36}$ See Notice 2018-28, supra note $34, \S 1$, at 492.

${ }^{37} I d . \S 3$, at 493 .

${ }^{38} \mathrm{Id}$. Section 59A(c)(3) also provides coordination rules for new $\S 163(\mathrm{j})$ and the BEAT in determining modified taxable income where the taxpayer is subject to interest deduction limitations, providing that any reduction in a taxpayer's interest deduction under $\S 163(\mathrm{j})$ is first allocated to interest paid to third parties, then to related parties. See I.R.C. § 59A(c)(3); see also Notice 2018-28, supra note $34, \S 1$, at 492 .

Pitt Tax Review | ISSN 1932-1821 (print) 1932-1996 (online) DOI 10.5195/taxreview.2018.82 | http://taxreview.law.pitt.edu 
Notice 2018-28 also indicated that proposed regulations would apply new $\S 163(\mathrm{j})$ at the consolidated group level. ${ }^{39}$

Treasury and the IRS released proposed regulations under new $\S 163(\mathrm{j})$ on November $26,2018 .{ }^{40}$ The proposed regulations are generally consistent with Notice 2018-28. For example, the proposed regulations confirm that new $\S 163(\mathrm{j})$ applies on the consolidated group level. ${ }^{41}$ Also, the proposed regulations confirm that all interest income and interest expense of a corporate taxpayer are business interest income and expense. ${ }^{42}$ However, the proposed regulations introduce a number of new rules and definitions that appear to expand the scope of new $\S 163(\mathrm{j})$ beyond the statutory language. For instance, the proposed regulations contain a definition of "interest" that includes not only items that are generally considered interest for tax purposes but also certain "interest equivalents," such as income, deduction, gain, or loss on certain hedging transactions; ${ }^{43}$ guaranteed payments for the use of capital ${ }^{44}$ and debt issuance costs. ${ }^{45}$

In addition, the proposed regulations provide that new $\S 163(\mathrm{j})$ applies to controlled foreign corporations $(\mathrm{CFCs})^{46}$ as well as foreign persons with effectively connected income. ${ }^{47}$ The proposed regulations do not address the

\footnotetext{
${ }^{39}$ Notice 2018-28, supra note $34, \S 5$, at 494 .

${ }^{40}$ Press Release, Internal Revenue Serv., IRS Issues Proposed Regulations on New Business Interest Expense Deduction Limit (Nov. 26, 2018), https://www.irs.gov/newsroom/irs-issues-proposedregulations-on-new-business-interest-expense-deduction-limit. The proposed regulations were published in the Federal Register on December 28, 2018 but, as of this writing, were not yet available through the Internal Revenue Bulletin. Limitation on Deduction for Business Interest Expense, 83 Fed. Reg. 67,490 (Dec. 28, 2018).

${ }^{41}$ Limitation on Deduction for Business Interest Expense, Prop. Treas. Reg. § 1.163(j)-4(d)(2), 83 Fed. Reg. 67,490, 67,547.

${ }^{42} I d$. $\S 1.163(\mathrm{j})-4(\mathrm{~b})(1), 83$ Fed. Reg. at 67,544 .

${ }^{43} I d$. $\S 1.163(\mathrm{j})-1(\mathrm{~b})(20)(\mathrm{iii})(\mathrm{E})-(\mathrm{F}), 83 \mathrm{Fed}$. Reg. at 67,540 (subsection E applies to issuers and subsection $\mathrm{F}$ applies to holders).

${ }^{44} I d$. $\S 1.163(\mathrm{j})-1(\mathrm{~b})(20)($ iii)(I), 83 Fed. Reg. at 67,540.

${ }^{45} \mathrm{Id}$. $1.163(\mathrm{j})-1(\mathrm{~b})(20)(\mathrm{iii})(\mathrm{H}), 83$ Fed. Reg. at 67,540.

${ }^{46} I d$. 1 1.163(j)-7(b), 83 Fed. Reg. at 67,576.

${ }^{47} I d . \S 1.163(\mathrm{j})-8(\mathrm{~b}), 83$ Fed. Reg. at 67,582.
}

Pitt Tax Review | ISSN 1932-1821 (print) 1932-1996 (online) DOI 10.5195/taxreview.2018.82 | http://taxreview.law.pitt.edu 


\section{8 |Pittsburgh Tax Review | Vol. 162018}

interaction of new $\S 163(\mathrm{j})$ and the BEAT ${ }^{48}$ However, as discussed below, recently proposed BEAT regulations address the interaction of these two provisions and, contrary to Notice 2018-28, provide that disallowed interest expense under old $\S 163(\mathrm{j})$ that was paid or accrued to a foreign related party and carried forward to a taxable year beginning after December 31, 2017, which is otherwise deductible in such year, will not be treated as a base erosion payment for purposes of $\S 59 \mathrm{~A} .{ }^{49}$ The regulations are proposed to apply to tax years ending after the date of publication of the final regulations in the Federal Register. ${ }^{50}$

Comments on the proposed regulations are due February 26, 2019. ${ }^{51}$ Significant comments on the proposed regulations are expected from taxpayers and tax practitioners. Whether these comments will result in final regulations materially different from the proposed regulations remains to be seen.

\section{THE BEAT}

Another significant anti-base erosion provision included as part of the TCJA that has broad impact is new $\S 59 \mathrm{~A}$ - commonly referred to as the BEAT. The BEAT provides for what is akin to an alternative minimum tax generally applicable to large multinational companies, ${ }^{52}$ and it is effective for tax years beginning after December $31,2017 .{ }^{53}$ If applicable, the BEAT provides for a minimum tax rate of $5 \%$ for $2018,10 \%$ for years 2019 through

${ }^{48} I d . \S 1.163(\mathrm{j})-11(\mathrm{~b})(5), 83$ Fed. Reg. at 67,544.

${ }^{49}$ Base Erosion Payments and Base Erosion Tax Benefits, Prop. Treas. Reg. § 1.59A-3(b)(3)(vi), 2019-2 I.R.B. 300, 330.

${ }^{50}$ Limitation on Deduction for Business Interest Expense, Proposed Applicability/Effective Dates, 83 Fed. Reg. at 67,526 ("Except as otherwise provided in this section, the regulations are proposed to be effective for taxable years ending after the date the Treasury decision adopting these regulations as final is published in the Federal Register.").

${ }^{51} I d$. at 67,490 .

${ }^{52}$ See I.R.C. § 59A(a).

${ }^{53}$ See id.; see also Tax Cuts and Jobs Act, Pub. L. No. 115-97, § 14401(e), 131 Stat. 2054, 2234 (2017).

Pitt Tax Review | ISSN 1932-1821 (print) 1932-1996 (online) DOI 10.5195/taxreview.2018.82 | http://taxreview.law.pitt.edu 
2025 , and $12.5 \%$ thereafter (to address budgetary concerns in enacting the TCJA) ${ }^{54}$

\section{A. Description of the BEAT}

As noted, the BEAT generally applies to large multinational companies. ${ }^{55}$ Specifically, the BEAT applies to corporations (other than a RIC, REIT, or S corporation) whose average annual gross receipts for the prior three-year period are at least $\$ 500$ million, and whose "base erosion percentage" (generally, the percentage of its overall deductions that relate to base erosion payments) is at least $3 \% .{ }^{56}$ These two thresholds, gross receipts and the base erosion percentage, are determined on a controlled-group basis, ${ }^{57}$ notwithstanding that the actual BEAT liability is calculated at the separate-entity level. ${ }^{58}$ As a result, large foreign-based multinational companies with relatively small U.S. operations may nevertheless be subject to the BEAT. ${ }^{59}$

If applicable, the BEAT generally applies to otherwise deductible payments made to foreign related parties and relates to cross-border intercompany loans, licenses, and services. ${ }^{60}$ To this end, a payment subject

${ }^{54}$ I.R.C. $\S 59 \mathrm{~A}(\mathrm{~b})(1)(\mathrm{A}),(2)(\mathrm{A})$. The rates are increased by $1 \%$ for banks and certain securities dealers. See id. § 59A(b)(3).

${ }^{55} I d . \S 59 \mathrm{~A}(\mathrm{e})(1)(\mathrm{B})$.

${ }^{56}$ The base erosion percentage is $2 \%$ for banks and certain securities dealers. Id. $\S 59 \mathrm{~A}(\mathrm{e})(1)(\mathrm{C})$.

${ }^{57}$ See id. $\S 59 \mathrm{~A}(\mathrm{e})(3)$. Section $59 \mathrm{~A}(\mathrm{e})(3)$ treats all entities as a single employer under $\S 52(\mathrm{a})$. The single employer is a single person for purposes of computing the base erosion percentage and the gross receipts test; however, in applying § 1563(a) (which is cross-referenced in $\S 52$ ), the exception for foreign corporations, under $\S 1563(\mathrm{~b})(2)(\mathrm{C})$, is disregarded.

${ }^{58}$ Specifically, a corporation's affiliated group consists of corporations in its chain of ownership, which are affiliated by $50 \%$ or more ownership, by vote or value. See id. $\S 59 \mathrm{~A}(\mathrm{e})(3), 1563(\mathrm{a})(1)$. For this purpose, foreign corporations are included; however, in determining income that is connected with the conduct of a trade or business, only gross receipts within the United States are taken into account. See id. $\S 59 \mathrm{~A}(\mathrm{e})(2)(\mathrm{A}),(\mathrm{e})(3)$.

${ }^{59}$ See id. § 59A(e)(2)(A), (e)(3).

${ }^{60} I d . \S 59 \mathrm{~A}(\mathrm{~d})(1)-(3)$. Specifically, a base erosion payment generally is an amount a taxpayer pays or accrues to a related foreign person for which a deduction is allowable, as well as amounts paid or accrued in connection with the acquisition of property subject to depreciation or amortization or for certain reinsurance payments. See id. The term base erosion payment also includes payments to certain "surrogate foreign corporations" (e.g., inverted companies) as well as foreign persons that are members of the same

Pitt Tax Review | ISSN 1932-1821 (print) 1932-1996 (online) DOI 10.5195/taxreview.2018.82 | http://taxreview.law.pitt.edu 


\section{0 |Pittsburgh Tax Review | Vol. 162018}

to the full withholding tax is not added back in computing a company's modified taxable income (and only a portion is added back if the payment is subject to a reduced withholding tax rate). ${ }^{61}$

Certain payments are not base erosion payments and are added back when computing a company's modified taxable income. For example, payments to foreign related parties that are properly accounted for as part of the cost of goods sold (COGS) (e.g., purchases of inventory) are not deductible payments, and therefore are not base erosion payments. ${ }^{62}$ Because of this favorable tax treatment for amounts included as part of COGS, ${ }^{63}$ taxpayers should consider the extent to which any otherwise deductible amounts are properly capitalizable as an inventory cost (and if so, whether a change in their method of accounting would be required). Another type of excluded payment is the cost portion of any payments for services that are eligible for the "services cost method under [§] 482" (as modified by the BEAT provisions) ${ }^{64}$ Finally, a base erosion payment does not include a payment made pursuant to a derivative if certain requirements are satisfied. ${ }^{65}$

Importantly, the BEAT does not take away an otherwise allowable deduction. In this sense, it is different from new $\S 163(\mathrm{j})$, which can defer

affiliated group as the surrogate foreign corporation. $I d$. $\$ 59 \mathrm{~A}(\mathrm{~d})(4)$. For purposes of the BEAT, the term "related party" includes: (1) any $25 \%$ owner of the taxpayer (by vote or value), (2) any person who is related (within the meaning of $\S 267$ (b) or $\S 707$ (b)(1)) to the taxpayer or any $25 \%$ owner of the taxpayer, and (3) any other person who is related (within the meaning of $\S 482)$ to the taxpayer. See id. $\S 59 \mathrm{~A}(\mathrm{~g})(1)$.

${ }^{61}$ See id. $\S \S 59 \mathrm{~A}(\mathrm{c})(2)(\mathrm{B}), 1441(\mathrm{a})-(\mathrm{b})$.

${ }^{62}$ See H.R. ReP. No. 115-466, at 657 (2017) (Conf. Rep.). ("Base erosion payments do not include ... payments for costs of goods sold.").

${ }^{63} I d$.

${ }^{64}$ I.R.C. $\S 59 \mathrm{~A}(\mathrm{~d})(5)(\mathrm{A})$. Specifically, an amount paid or accrued by a taxpayer for services will not be a base erosion payment if:

(A) such services are services which meet the requirements for eligibility for use of the services cost method under [\$] 482 (determined without regard to the requirement that the services not contribute significantly to fundamental risks of business success or failure), and (B) such amount constitutes the total services cost with no markup component.

Id. $\S 59 \mathrm{~A}(\mathrm{~d})(5)$.

${ }^{65}$ See id. $\S 59 \mathrm{~A}(\mathrm{~h})(1)-(2)$.

Pitt Tax Review | ISSN 1932-1821 (print) 1932-1996 (online)

DOI 10.5195/taxreview.2018.82 | http://taxreview.law.pitt.edu 
interest expense deductions. ${ }^{66}$ Instead, it remedies the U.S. tax base reduction by imposing a tax equal to the excess of (1) 10\% (for years 2019-2025) of a taxpayer's "modified taxable income" over (2) the taxpayer's normal tax liability (determined without regard to certain credits). ${ }^{67}$ A taxpayer's modified taxable income is equal to its taxable income computed without regard to deductions for base erosion payments, as well as the base erosion percentage of the taxpayer's net operating loss deduction for the year. ${ }^{68}$

As a grossly simplified example, if a U.S. company has $\$ 200$ of taxable income, after deducting $\$ 300$ interest paid to a foreign affiliate (assuming no other deductions), it would compare $10 \%$ of the $\$ 500$ "grossed up" income (i.e., \$50) with its normal tax liability (i.e., $\$ 42$, assuming a $21 \%$ tax rate on $\$ 200$ taxable income). The difference, $\$ 8$, would equal the taxpayer's BEAT liability. In real life, as with many other tax regimes, the BEAT calculation is more complicated when taking into account adjustments provided for by certain tax credits and net operating loss deductions, ${ }^{69}$ as well as exceptions to the types of payments that constitute base erosion payments. ${ }^{70}$

Finally, Congress understood that $\S 163(\mathrm{j})$ and the BEAT could overlap - for instance, both could apply to interest deductions on debt issued by U.S. corporations to foreign related parties. To this end, the BEAT specifically provides that amounts disallowed under $\S 163(\mathrm{j})$ shall be allocable first to debt issued to unrelated third parties. ${ }^{71}$ In so doing, the amount of interest deductions required to be added back in computing the taxpayer's BEAT liability is maximized.

${ }^{66}$ See id. § 163(j)(1)-(2).

${ }^{67} I d$. $\$ 59 \mathrm{~A}(\mathrm{~b})(1)(\mathrm{A})-(\mathrm{B})$. Specifically, the taxpayer's regular tax liability is reduced (but not below zero) by the excess of credits allowed under Chapter 1 over the sum of: credits allowed under $\S 38$ that are properly allocable to the research credit under $\S 41$, plus the portion of the applicable $\S 38$ credits not in excess of $80 \%$ of the lesser of the amount of such credits or the base erosion minimum tax amount (determined without regard to the applicable $\S 38$ credits). Id. $\S 59 \mathrm{~A}(\mathrm{~b})(1)(\mathrm{B})$.

${ }^{68} I d . \S 59 \mathrm{~A}(\mathrm{c})(1)$.

${ }^{69}$ See id. § 59A(b)(1)(B)-(c)(1)(B).

${ }^{70}$ See id.

${ }^{71} \mathrm{Id}$.

Pitt Tax Review | ISSN 1932-1821 (print) 1932-1996 (online) DOI 10.5195/taxreview.2018.82 | http://taxreview.law.pitt.edu 


\section{2 |Pittsburgh Tax Review | Vol. 162018}

\section{B. Regulatory and Administrative Guidance}

Section 59A grants Treasury broad authority to issue antiavoidance regulations. ${ }^{72}$ Under the broad grant of regulatory authority, Treasury and the IRS issued proposed regulations under $\S 59 \mathrm{~A}$ on January $7,2019 .{ }^{73}$ The proposed regulations address a wide range of issues, including many of the questions left unanswered in the statute. For example, with respect to partnerships, the proposed regulations provide that partnerships are treated as an aggregate of their partners. ${ }^{74}$ Therefore, whether payments made or received by a partnership are base erosion payments is determined at the partnership level. ${ }^{75}$ The proposed regulations also address whether payments subject to U.S. tax are base erosion payments, providing that payments constituting effectively connected income to the recipient are not base erosion payments. ${ }^{76}$ A similar exception is not included for amounts includible by a U.S. shareholder as Subpart F or GILTI income. ${ }^{77}$ Finally, as noted above, the proposed regulations provide a number of rules regarding the interaction of the BEAT rules with new $\S 163(\mathrm{j}) .^{78}$

The BEAT regulations are proposed to be effective for tax years ending after December 31, $2017^{79}$ (i.e., retroactive to the effective date of $\S 59 \mathrm{~A}$, which applies to base erosion payments paid or accrued in tax years beginning after December 31, 2017). ${ }^{80}$ Comments on the proposed

${ }^{72}$ See I.R.C. § 59A(i).

${ }^{73}$ Base Erosion Payments and Base Erosion Tax Benefits, 2019-2 I.R.B. 300, 300.

${ }^{74}$ Id. § 1.59A-7(a)-(b), 2019-2 I.R.B. at 336-37.

${ }^{75}$ Id. $\S 1.59$ A-7(b)(2)-(4), 2019-2 I.R.B. at 336-37.

${ }^{76} I d$. $~ 1.59$ A-3(b)(3)(iii), 2019-2 I.R.B. at 330 .

${ }^{77}$ See id. §1.59A-3(b)(3), 2019-2 I.R.B. at 330.

${ }^{78}$ E.g., id. § 1.59A-3(c)(4), 2019-2 I.R.B. at 332.

${ }^{79} \mathrm{Id}$. at 317 (" $[\mathrm{I}] \mathrm{f}$ any provision is finalized after June 22, 2019, the Treasury Department and the IRS generally expect that such provision will apply only to taxable years ending on or after December 17, 2018.”).

${ }^{80}$ E.g., Tax Cuts and Jobs Act, Pub. L. No. 115-97, § 14401(e), 131 Stat. 2054, 2234 (2017).

Pitt Tax Review | ISSN 1932-1821 (print) 1932-1996 (online) DOI 10.5195/taxreview.2018.82 | http://taxreview.law.pitt.edu 
regulations are due February 19, 2019, ${ }^{81}$ and significant comments from taxpayers and tax practitioners are expected.

\section{CONCLUDING REMARKS}

In issuing proposed regulations under new $\S 163(\mathrm{j})$ and the BEAT, Treasury and the IRS answered many previously unanswered questions and raised many more. Significant comments are expected, meaning Treasury and the IRS will have their hands full as they attempt to address such comments and release final regulations. Given that final regulations are expected later this year, commenters and other interested parties won't need to wait long to know how Treasury and the IRS respond to their comments. Then, the fun can begin again.

${ }^{81}$ Base Erosion Payments and Base Erosion Tax Benefits, 2019-2 I.R.B. at 300 (the portion of the preamble that discusses the timing of public comments).

Pitt Tax Review | ISSN 1932-1821 (print) 1932-1996 (online) DOI 10.5195/taxreview.2018.82 | http://taxreview.law.pitt.edu 